\title{
De koers van de Hoge Raad: (on)voorspelbaar?
}

\author{
Prof. mr. C.J.M. Klaasen*
}

\section{Inleiding; vraagstelling}

Op vrijdag 4 oktober 2002 mocht ik spreken over werkgeversaansprakelijkheid op een congres voor letselschadeadvocaten. $\mathrm{Nu}$ overkomt het me wel vaker, dat ik mag spreken op een congres, en het was ook niet de enige of eerste keer dat ik sprak over werkgeversaansprakelijkheid. Toch is deze bijeenkomst mij in het bijzonder bijgebleven. Waarom? Omdat de Hoge Raad zojuist uitspraak had gedaan in de zogenoemde Broodmes-zaak ofwel het arrest Laudy/Fair Play. ${ }^{1}$ Het ging in deze zaak om de vraag of werkgever Fair Play aansprakelijk was voor de schade die zijn werkneemster, mevrouw Laudy, had opgelopen doordat zij zich in haar wijsvinger had gesneden toen zij in het kader van haar werkzaamheden zachte puntbroodjes moest snijden en smeren. Mevrouw Laudy had een zenuw geraakt, hetgeen tot spierdystrofie en daardoor arbeidsongeschiktheid had geleid. Mevrouw Laudy stelde dat er sprake was van een nieuw broodmes dan wel een mes dat net geslepen was en dus scherp, en scherper dan door haar verwacht. Laudy verwijt haar werkgever (onder andere) dat deze haar hierover niet heeft geïnformeerd. Voor degenen die minder zijn ingevoerd in het aansprakelijkheidsrecht: voor zover in dit verband van belang, is de werkgever op grond van art. 7:658 BW aansprakelijk voor de schade die een werknemer in de uitoefening van zijn werkzaamheden oploopt, tenzij hij, werkgever, bewijst dat hij aan zijn zorgplicht heeft voldaan; dat wil zeggen, dat hij al die maatregelen heeft genomen die in de gegeven omstandigheden redelijkerwijs van hem konden worden gevergd om schade aan de kant van de werknemer te voorkomen. De lat wordt voor de werkgever in dit opzicht hoog gelegd, en in elk geval was dit het geval in de rechtspraak tot aan het Broodmes-arrest. Naar aanleiding van de rechtspraak over de inkleuring van deze zorgplicht werd zelfs wel gezegd dat de aansprakelijkheid van de werkgever weliswaar formeel was gebaseerd op schending van diens zorgplicht, maar er in feite sprake was van een risicoaansprakelijkheid. Tegen deze achtergrond werd het Broodmes-arrest gewezen. De aanwezigen op voormeld congres kenden de uitspraak van de Hoge

\footnotetext{
Mw. prof. mr. C.J.M. Klaassen is hoogleraar burgerlijk recht en burgerlijk procesrecht aan de Radboud Universiteit Nijmegen. Deze bijdrage betreft de enigszins bewerkte versie van de inleiding gehouden ter gelegenheid van het door het CPO Nijmegen georganiseerde symposium ter ere van het afscheid van A. Hammerstein als CPO-wisselleerstoelhouder. Het overkoepelende thema van dit op 18 juni 2015 gehouden symposium was 'Cassatie en de taak van de cassatierechter'.

1. HR 4 oktober 2002, NJ 2004/175 m.nt. GHvV onder HR 12 september 2003, NJ 2004/177 (Peters/Schoonmaakbedrijf Hofkens).
}

Raad in deze zaak kennelijk nog niet. Ik hield hun de casus voor en vroeg hun door middel van handopsteken kenbaar te maken wat zij dachten dat de uitkomst van het arrest zou zijn: werkgever in het gelijk gesteld en geen aansprakelijkheid, dan wel werknemer in het gelijk gesteld en aanspraak op schadevergoeding. ${ }^{2}$ Vrijwel unaniem werd verwacht dat de werknemer in het gelijk zou zijn gesteld en aanspraak zou kunnen maken op schadevergoeding. Weliswaar werd door sommigen opgemerkt dat ze dit eigenlijk te zot vonden, maar dat een dergelijke uitkomst te verwachten was, gelet op de eerdere rechtspraak van de Hoge Raad. Aldus pakte het echter niet uit! De Hoge Raad verwierp het cassatieberoep gericht tegen het oordeel van de rechtbank, ${ }^{3}$ dat Fair Play door haar werknemers niet te waarschuwen voor het nieuwe (of geslepen) broodmes niet is tekortgeschoten in haar zorgplicht op grond van art. 7:658 BW. Dit oordeel is art. 7:658 lid 1 niet onbegrijpelijk en behoefde geen nadere motivering, aldus de Hoge Raad, 'in aanmerking genomen dat van algemene bekendheid is dat een mes dat geschikt is om zachte puntbroodjes mee te snijden zo scherp is dat de gebruiker daarvan het gevaar loopt zich bij dat werk te snijden'. De gedachtegang van de Hoge Raad is blijkbaar dat een dergelijk mes inherent scherp is en de omstandigheid dat er sprake is van een nieuw of net geslepen mes daarom niet relevant is.

Hartlief kopte naar aanleiding van deze beslissing: 'Werkgeversaansprakelijkheid ex art. 7:658. Een nieuwe wind in de Kazernestraat'. ${ }^{4}$ Vegter met: 'De Hoge Raad trapt op de rem'. Brochures voor cursussen en congressen lokten met kreten als 'opzienbarende jurisprudentie van de Hoge Raad' en 'Tot voor kort werd door velen aangenomen dat de aansprakelijkheid voor arbeidsongevallen en beroepsziekten praktisch gesproken een risicoaansprakelijkheid was. Met de arresten Laudy/Fair Play en Dusarduyn/Du Puy heeft de Hoge Raad hierin recentelijk verandering gebracht.' Of dit zo is, laat ik hier in het midden. Waar het mij in dit verband om gaat, is het effect dat uitgaat van een uitspraak van de Hoge Raad.

2. Processueel bezien ging het om de vraag of het vonnis van de rechtbank, waarbij de vordering van Laudy was afgewezen, door de Hoge Raad zou worden vernietigd. De kantonrechter had de vordering toegewezen en Fair Play aansprakelijk geoordeeld op grond van art. 7:658 BW.

3. Destijds was de rechtbank nog de appelinstantie van beslissingen van de kantonrechter, zoals uitspraken in zaken betreffende art. 7:658 BW.

4. T. Hartlief, Werkgeversaansprakelijkheid ex art. 7:658. Een nieuwe wind in de Kazernestraat, WPNR 2003, p. 934.

5. M.S.A. Vegter, De Hoge Raad trapt op de rem, Bb 2003, p. 197. 
De rechtspraak van de Hoge Raad wordt door de zogenoemde lagere rechters, ofwel de feitenrechters, de advocatuur, althans het goede deel daarvan, en de wetenschap nauwlettend in het oog gehouden. De door de Hoge Raad uitgezette koers pleegt door de feitenrechters in de regel te worden gevolgd $^{6}$ en de advocaat stemt hierop zijn adviezen en processtukken af. De wetenschap, op haar beurt, pleegt de rechtspraak van de Hoge Raad onder een vergrootglas te leggen en tot op het bot te analyseren. Hoe moet het desbetreffende arrest worden uitgelegd? Past het in de lijn van de eerdere rechtspraak of wordt de koers bijgesteld of zelfs gewijzigd, en zo ja, wat betekent dit dan voor andersoortige zaken? Het is opmerkelijk hoe verschillend wij wetenschappers een arrest van de Hoge Raad in dit verband soms kunnen uitleggen, daarbij al dan niet gestuurd door wat door Jan Vranken is genoemd 'wensdenken', 7 omdat dit in het eigen (redenerings)straatje van pas komt. Diametraal verschillende interpretaties van niet alleen de betekenis van een arrest in de lijn der ontwikkelingen, maar ook van de tekst van een arrest zijn hierbij geen uitzondering. Wellicht dat de Hoge Raad soms met verbazing kennisneemt van hetgeen hem aan achterliggende gedachten en intenties wordt toegedicht. Soms overdrijven onderzoekers misschien in het kader van deze fileer- en interpreteerarbeid, zoals Vranken oppert in zijn laatste Asser-boek, en menen zij daardoor in een arrest ontwikkelingen te zien, die er niet zijn. ${ }^{8}$ Regelmatig biedt een arrest niettemin ook de nodige ruimte voor uiteenlopende interpretaties en is hiermee weliswaar een beslissing gegeven en een knoop doorgehakt in het desbetreffende geval, maar roept het arrest voor het overige meer vragen op dan ermee worden beantwoord. Het Broodmes-arrest bijvoorbeeld heeft een reeks aan rechtszaken uitgelokt over de al dan niet verschoven grens wat betreft de zorgplicht van de werkgever. Hoewel dit de wetenschap, en dus ook mij, van de straat houdt, is het de vraag of dit wenselijk is. De Hoge Raad heeft tot taak de rechtseenheid en de rechtsontwikkeling te bevorderen. ${ }^{9}$ Geschiedt dit echter wel op een goede manier als de Hoge Raad uitleg geeft aan bestaande regels of nieuwe regels ontwikkelt op een wijze die weinig houvast biedt of richting geeft, waardoor beslissingen in toekomstige gevallen moeilijk voorspelbaar zijn? Dat is de kwestie waarop ik graag wil ingaan. Ik wil enkele opmerkingen maken over de vanuit het legioen van Hoge Raad-watchers zoals dat door Coen Drion is gedoopt ${ }^{10}$ - regelmatig geplaatste kritische kanttekeningen bij de rechtspraak van de Hoge Raad, met name daar waar het betreft vermeende inconsistenties, wonderlijke of zelfs - vermeend - foute beslissingen dan wel veronderstelde keuzes. Om vervolgens in te gaan op de

6. Tenzij er aanleiding wordt gezien om een koerswijziging in gang te zetten.

7. Asser/Vranken Algemeen deel ${ }^{* * * *} 2014 / 111$, p. 132.

8. Asser/Vranken Algemeen dee ${ }^{* * * *}$ 2014/111, p. 132. Dit boek heeft mede tot het overkoepelende thema van het symposium d.d. 18 juni 2015 geïnspireerd.

9. Vgl. art. 81 Wet RO.

10. C. Drion, NJBlog 'HR Watching' van 16 juni 2014, te raadplegen via $<$ http://njb.nl/blog/hr-watching.12295.lynkx >, en het interview gepubliceerd in Mr. 2015, p. 18-23 vraag: kan en moet het anders, en zo ja, hoe zou dat dan moeten?

\section{Enkele opmerkelijke arresten; een bloemlezing op het terrein van het aansprakelijkheidsrecht}

2.1. Voordat ik probeer een antwoord te geven op deze vraag, laat ik eerst enkele arresten de revue passeren die vragen oproepen en lijken te getuigen van enige wispelturigheid en daarmee onvoorspelbaarheid van de Hoge Raad. Dit om te illustreren dát Hoge Raads wegen soms ondoorgrondelijk en moeilijk voorspelbaar zijn en om daarmee tegemoet te komen aan Vranken, die in zijn laatste Asser-boek stelt dat wetenschappers regelmatig oplossingen zoeken voor niet-bestaande problemen. ${ }^{11} \mathrm{Ik}$ heb bij mijn selectie van verrassende uitspraken, uitspraken die vragen oproepen en uitspraken die een opmerkelijk beeld geven als men ze naast elkaar plaatst, gekozen voor uitspraken op het gebied van het aansprakelijkheidsrecht. Vanuit andere rechtsgebieden kan echter eenzelfde soort bloemlezing worden gegeven. ${ }^{12}$

Allereerst een enkel arrest op het gebied van de werkgeversaansprakelijkheid. Ik memoreerde al dat het Broodmesarrest een aanmerkelijk aantal andere rechtszaken heeft uitgelokt over de zorgplicht van de werkgever. Diverse van deze zaken hebben de Hoge Raad gehaald. Opvallend is dat de Hoge Raad hierin veelvuldig afwijkt van de conclusie van de advocaat-generaal. Dit is ook het geval in het arrest Dusarduyn/Du Puy, ${ }^{13}$ een arrest dat naar mijn mening eigenlijk opmerkelijker is dan het Broodmes-arrest. Het betrof hier dakdekker Dusarduyn, die door zijn werkgever op pad was gestuurd om dakdekwerkzaamheden te verrichten bij een particulier die een bijkeuken had laten aanbouwen. Op het dak van deze bijkeuken moest door een ander bedrijf een lichtkoepel worden aangebracht. Het gat voor deze lichtkoepel was al uitgezaagd, maar het was afgedekt met isolatiemateriaal. Als Dusarduyn op het dak loopt om te bekijken hoe hij een en ander gaat aanpakken, stapt hij over de rand van de lichtkoepel, waarna hij door het isolatiemateriaal zakt en ongeveer 2,80 meter naar beneden valt, met ernstig letsel tot gevolg. Dusarduyn spreekt zijn werkgever Du Puy aan en vordert een verklaring voor recht dat Du Puy jegens hem aansprakelijk is voor de schade vanwege voormeld ongeval. De kantonrechter wijst deze vordering af. De rechtbank bekrachtigt deze uitspraak. Zij acht in dit verband van belang dat het ging om een eenvoudig karwei met beperkte omvang met daarbij naar redelijke verwachting beperkte veiligheidsrisico's. In aanmerking nemende dat Du Puy niet wist dat er een lichtkoepel in het dak zou worden geplaatst, behoefde Du Puy zich niet zelf op de hoogte te stellen van mogelijke risico's en mocht zij Dusarduyn, die een ervaren dakdekker was en in het bezit was van een veiligheidsdiploma, in staat achten zelf de risico's verbon-

11. Asser/Vranken Algemeen deel**** 2014/42, p. 52. Kritisch op dit punt overigens de boekbespreking van A. Verheij, Ars Aequi 2015, p. 416-418.

12. Vgl. bijv. wat betreft het goederen- en insolventierecht R.M. Wibier, De Hoge Raad op drift?, WPNR 2015, p. 49-57.

13. HR 16 mei 2003, NJ 2004/176 m.nt. GHvV onder HR 12 september 2003, NJ 2004/177 (o.a.) door schrijver dezes geannoteerd in AV\&S 2003, p. $227-232$. 
den aan het karwei te beoordelen en te handelen naar bevind van zaken. Naar het oordeel van de Hoge Raad geeft de rechtbank niet blijk van een onjuiste rechtsopvatting door op grond van enerzijds de aard van de betrokken werkzaamheden en anderzijds de werkervaring van Dusarduyn en diens uit het bezit van een veiligheidsdiploma blijkende kennis te oordelen dat Du Puy niet in haar zorgplicht tekort is geschoten. Dit oordeel kan voor het overige, vanwege de verwevenheid met waarderingen van feitelijke aard, niet op juistheid worden getoetst en behoefde geen nadere motivering, aldus de Hoge Raad. In hoeverre de Hoge Raad inderdaad vanwege verwevenheid met de feiten niet verdergaand kon toetsen, laat ik rusten. ${ }^{14}$ Ik volsta met de opmerking dat de advocaat-generaal, De Vries Lentsch-Kostense, kennelijk wel ruimte en aanleiding zag om te casseren. $\mathrm{Zij}$ komt tegen de achtergrond van de eerdere jurisprudentie van de Hoge Raad tot de conclusie dat het oordeel van de rechtbank blijk geeft van een onjuiste rechtsopvatting. Zoals vermeld: de Hoge Raad komt tot een ander oordeel. Wat er zij van de cassatietechnische kant, de uitkomst dat Dusarduyn zijn werkgever niet kan aanspreken voor zijn schade, is aan leken, maar ook aan juristen, moeilijk of niet uit te leggen als men deze plaatst naast de uitkomst van het arrest Pollemans/Hoondert. ${ }^{15}$ Daar ging het eveneens om een werknemer die tijdens zijn werkzaamheden van het dak valt en daarbij letsel oploopt, waarvoor hij zijn werkgever aansprakelijk stelt: ondanks dat hij door zijn werkgever herhaaldelijk en in krachtige bewoordingen is gewaarschuwd niet buiten de steigerdelen te lopen, begeeft timmerman Pollemans zich tóch buiten de steigerdelen op het (golfplaten)dak en zakt daar vervolgens doorheen. In deze zaak wordt de werkgever (desondanks) wel aansprakelijk geoordeeld. Voor de goede orde, ik ben mij ervan bewust dat ik in zekere zin appels met peren vergelijk door Pollemans/Hoondert te plaatsen naast Dusarduyn/Du Puy, omdat de Hoge Raad in Dusarduyn/Du Puy diende te oordelen over de inkleuring van de zorgplicht en in Pollemans/Hoondert over de inkleuring van het criterium 'opzet of bewuste roekeloosheid'. ${ }^{16}$ De Hoge Raad oordeelde dat van bewuste roekeloosheid van de kant van een werknemer - en dus van verval van aansprakelijkheid van de werkgever - eerst sprake is als de werknemer zich tijdens het verrichten van zijn onmiddellijk aan het ongeval voorafgaande gedraging daadwerkelijk bewust is geweest van het roekeloze karakter hiervan. Deze conclusie mocht niet worden getrokken op grond van het gegeven dat werknemer Pollemans zich, ondanks de vaststaande herhaaldelijke en duidelijke waarschuwingen van zijn werkgever, buiten de steigerdelen begaf. Echter, wat er zij van de verschillende juridische 'sleutels' waarin beide arresten dienen te worden geplaatst, het is wat mij betreft onbevredigend dat werknemer Pollemans jegens zijn werkgever aanspraak kan maken op schadevergoeding, terwijl werknemer Dusarduyn met lege handen blijft staan; een uit-

14. Deze kwestie komt aan de orde in de bijdrage van Hammerstein aan het symposium, eveneens gepubliceerd in deze uitgave van TCR special.

15. HR 20 september 1996, NJ 1997/198.

16. Ingevolge art. 7:658 lid $2 \mathrm{BW}$ eveneens een omstandigheid die tot verval van de aansprakelijkheid van de werkgever leidt. komst die ten opzichte van de 'buitenwacht' ook lastig valt uit te leggen. Heerma van Voss merkt in zijn $N J$-noot bij een van de arresten over werkgeversaansprakelijkheid op grond van art. 7:658 BW op: 'arbeidsongevallen, art. 7:658 BW. De jurisprudentie over dit onderwerp heeft voor velen de afgelopen jaren een beeld van onvoorspelbaarheid opgeroepen.' ${ }^{17}$

2.2. Ondertussen wel redelijk voorspelbaar is de positie van een werknemer die schade heeft opgelopen in het verkeer. De Hoge Raad heeft hier immers, uiteindelijk, duidelijke lijnen getrokken en een 'overzichtsarrest' gewezen, zij het na eerst zelf onduidelijkheid te hebben gecreëerd. Niettemin: met als resultaat ook hier een niet goed uit te leggen verschil in positie van slachtoffers. Waar gaat het om? Terwijl 'normaliter' dus geldt dat de werkgever de schade die zijn werknemer in het kader van zijn werkzaamheden oploopt niet behoeft te vergoeden als de werkgever kan aantonen dat hij zijn zorgplicht met het oog op de veiligheid of de gezondheid van zijn werknemers heeft nageleefd, is dit in het verkeer anders. Voor schade opgelopen in het verkeer heeft de Hoge Raad een apart regime ontwikkeld. De Hoge Raad heeft op dit terrein immers een verzekeringsplicht van de werkgever aangenomen, of beter gezegd: gecreëerd, gebaseerd op de (algemene) verplichting van de werkgever zich als een goed werkgever te gedragen (art. 7:611 BW). In bepaalde gevallen is de werkgever ingevolge de rechtspraak van de Hoge Raad deswege aansprakelijk voor niet door een behoorlijke verzekering gedekte schade die de werknemer oploopt als deelnemer aan het verkeer. Anders dan bij aansprakelijkheid op grond van art. 7:658 BW, betreft de aansprakelijkheid op grond van art. 7:611 BW niet de door de werknemer opgelopen letsel- of zaakschade als zodanig, maar (slechts) de schade vanwege het ontbreken van een behoorlijke verzekering. Met andere woorden, deze aansprakelijkheid betreft het bedrag dat bij het bestaan van een behoorlijke verzekering zou zijn vergoed.

Deze aansprakelijkheid vanwege het nalaten werknemers behoorlijk te verzekeren werd aanvankelijk door de Hoge Raad aangenomen ter zake van schade die de werknemer als bestuurder van een motorrijtuig was overkomen. $\mathrm{Zij}$ was gekoppeld aan de aan het gemotoriseerde verkeer verbonden risico's en de goede verzekerbaarheid van deze risico's tegen betaalbare premies. Vrij vlot heeft de Hoge Raad de reikwijdte van de verzekeringsplicht echter uitgebreid. ${ }^{18} \mathrm{Zo}$ is uiteindelijk ook een verzekeringsplicht aanvaard ten gunste van thuishulp Van der Graaf, die met haar fiets op weg was van de ene cliënt naar de andere en daarbij ten val kwam als gevolg van gladheid. Aan deze valpartij kwam geen gemotoriseerd voertuig, met het daaraan verbonden bijzondere gevaar, te pas. Echter: ten aanzien van Manuela Wijenberg, die te voet als postbezorger ten val kwam door een plak ijs of bevroren snee-

17. HR 11 april 2008, NJ 2008/465 (Tarioui/Vendrig).

18. Voor een beknopte schets van de ontwikkelingen verwijs ik bijv. naar mijn beschouwing: De reikwijdte van de werkgeversaansprakelijkheid voor arbeidsongevallen na TNT/Wijenberg en De Rooyse Wissel/ Hagens en hoe nu verder?, NTBR 2012, p. 397-411 en de noot van Hartlief onder HR 11 november 2011, NJ 2011/597 (TNT/Wijenberg). 
uw, trapte de Hoge Raad op de rem wat betreft het beroep op schending van een verzekeringsplicht door werkgever TNT Post. De Hoge Raad casseert (na sprongcassatie) het vonnis van de kantonrechter, die wél een verzekeringsplicht had aangenomen (hetgeen in het licht van de eerdere rechtspraak van de Hoge Raad niet geheel verwondert). De Hoge Raad overweegt dat er op zichzelf goede argumenten bestaan om werknemers een verdergaande algemene bescherming tegen het risico van ongevallen in verband met hun werkzaamheden te bieden dan art. 7:658 BW thans biedt, maar het op de weg van de wetgever ligt om een regeling daarvoor te maken en dit zijn rechtsvormende taak te buiten gaat. De Hoge Raad voegt hieraan toe dat bij de huidige stand van de wetgeving, mede met het oog op de vereiste rechtszekerheid en de hanteerbaarheid van het recht, de in de rechtspraak aanvaarde, uit goed werkgeverschap voortvloeiende verzekeringsplicht van de werkgever beperkt dient te blijven tot de gevallen waarin dit in zijn eerdere rechtspraak is aangenomen (die in het arrest TNT/Wijenberg nog eens op een rijtje worden gezet). In aansluiting bij deze wat abrupte trap op de rem, overweegt de Hoge Raad in het op dezelfde dag gewezen arrest De Rooyse Wissel/Hagens dat er geen grond is voor het aannemen van een verzekeringsplicht ten behoeve van sociotherapeut Hagens, die als werknemer van De Rooyse Wissel bij de uitoefening van zijn werkzaamheden rake klappen had gekregen van een daar opgenomen tbs'er. ${ }^{19}$

Het NRC Handelsblad kopte naar aanleiding hiervan op 8 december 2011: 'Aansprakelijkheid van werkgevers is een soepzooitje geworden'. ${ }^{20}$ Deze krantenkop is ontleend aan de bijdrage van Waterman aan de rubriek 'De uitspraak' in het NRC Handelsblad naar aanleiding van het arrest De Rooyse Wissel. Ik laat deze kwalificatie graag voor rekening van Waterman, maar ik denk dat niemand, ook de Hoge Raad niet, kan ontkennen dat er inmiddels wat betreft de werkgeversaansprakelijkheid een lappendeken is ontstaan of, bezien vanuit de werknemersbescherming, wellicht veeleer een gatenkaas.

2.3. Echter: hoezeer min of meer willekeurig afgebakend, de bijzondere bescherming van werknemers die schade hebben opgelopen vanwege deelname aan het verkeer, steekt bijvoorbeeld nogal af tegen de lastige positie waarin werknemers die een beroepsziekte hebben opgelopen regelmatig verkeren; althans, de positie waarin werknemers verkeren die stellen ziek te zijn geworden door hun werk. Dit geldt met name als er sprake is van ziekte of van klachten waarvoor geen duidelijke oorzaak is aan te wijzen of die meerdere oorzaken kunnen hebben, zoals RSI, OPS, enzovoort. Het is in principe aan de werknemer om aan te tonen dát er sprake is van klachten opgelopen in de uitoefening van de werkzaamheden. Ondanks diverse pleidooien van de zijde van slachtofferadvocaten, komt de Hoge Raad deze werknemers slechts in beperkte mate tegemoet in het door hen te leveren causaliteitsbewijs. Aan een

19. HR 11 november 2011, NJ 2011/598 (De Rooyse Wissel/Hagens), m.nt. Hartlief onder NJ 2011/597.

20. Zie <www.nrc.nl/rechtenbestuur/2011/12/08>. beroep op de zogenoemde (arbeidsrechtelijke) omkeringsregel, ${ }^{21}$ met het daaraan verbonden vermoeden van causaal verband, worden dusdanige eisen gesteld dat dit slechts beperkte toegevoegde waarde heeft ten opzichte van het feitelijk vermoeden, terwijl het leerstuk van de proportionele aansprakelijkheid eveneens maar beperkt soelaas biedt en bovendien uit zijn aard slechts een aanspraak op gedeeltelijke schadevergoeding oplevert. Tegen min of meer vergelijkbare problemen lopen overigens niet alleen werknemers met een vermeende beroepsziekte aan, maar ook anderen die stellen ten gevolge van andermans fout niet-objectiveerbaar letsel te hebben opgelopen. Ik refereer aan de problematiek van de whiplashslachtoffers. Voor de goede orde: ik onderschrijf de door de Hoge Raad betrachte terughoudendheid wat betreft de toepassing van de omkeringsregel en een proportionele aansprakelijkheid. Echter: als ik, even los van de juridisch-technische aspecten en verklaringen daarvoor, 'onder de streep' naar het resultaat kijk, en dit vervolgens vergelijk met het resultaat waartoe de rechtspraak op het terrein van de bancaire aansprakelijkheid soms leidt, in het bijzonder wat betreft het tekortschieten in de informatie- en waarschuwingsplicht ten aanzien van tegenvallende beleggingsproducten of althans beleggingen, dan levert dit een opmerkelijk beeld op. Door de Hoge Raad is in dit verband een bijzondere zorgplicht aangenomen voor banken, althans ten opzichte van particuliere cliënten. Wat betreft het vervolgens door de gedupeerde te bewijzen causaal verband houdt de Hoge Raad weliswaar vast aan de hoofdregel, dat de cliënt dient te bewijzen dat hij niet tot de desbetreffende beleggingen was overgegaan als de bank aan haar zorgplicht had voldaan en hem deugdelijk over de risico's hiervan had geïnformeerd. En ook in dit verband heeft de Hoge Raad zich terughoudend opgesteld wat betreft het aannemen van een proportionele aansprakelijkheid in het geval voormelde bewijslevering problematisch blijkt te zijn. ${ }^{22}$ Evenmin lijkt een tegemoetkoming in het door de gedupeerde in beginsel te leveren causaliteitsbewijs door middel van de omkeringsregel direct in de rede te liggen, gelet op de rechtspraak van de Hoge Raad, althans niet daar waar (slechts) sprake is van schending van een informatieplicht en niet van schending van een expliciete waarschuwingsplicht. Niettemin lijkt de Hoge Raad op dit terrein gedupeerden anderszins tegemoet te komen. De Hoge Raad lijkt simpelweg de lat voor het aannemen van causaal verband op dit terrein vrij laag te leggen. Ik refereer bijvoorbeeld aan het arrest Rabobank Vaart en Vecht, ${ }^{23}$ voorafgegaan door een conclusie van Hammerstein. Hammerstein meent dat de feitenrechter te ver is gegaan en het recht niet juist heeft toegepast. De Hoge Raad daarentegen oordeelt dat dit niet het geval is en beschouwt voor het overige de oordelen van het hof als sterk feitelijk (en dus in cassatie niet aantastbaar). Uit deze terughoudende opstelling van de Hoge Raad

21. Zie laatstelijk HR 7 juni 2013, ECLI:NL:HR:2013:BZ1717 (SVB/Van de Wege) en HR 7 juni 2013, ECLI:NL:HR:2013:BZ1721 (Lansink/ Ritsma).

22. HR 24 december 2010, NJ 2011/251 m.nt. T.F.E. Tjon Tjin Tai (Fortis/ Bourgonje).

23. HR 3 februari 2012, NJ 2012/95. 
en zijn 'welwillende' bejegening van het arrest van het hof kan naar mijn mening worden geconcludeerd dat de Hoge Raad een zekere soepelheid onderschrijft wat betreft het aannemen van causaal verband in kwesties betreffende schending van een informatie- of waarschuwingsplicht door de bank tegenover in elk geval een particulier. ${ }^{24}$ Eenzelfde conclusie kan bijvoorbeeld worden getrokken uit het arrest Van Lanschot Bankiers/ MAIG c.s. ${ }^{25}$

2.4. Ik kan deze bloemlezing aanvullen met vele andere opmerkelijke beslissingen van de Hoge Raad. Denk bijvoorbeeld aan het Hangmat-arrest, ${ }^{26}$ waarin op grond van een mijns inziens niet daadwerkelijk waterdichte redenering een risicoaansprakelijkheid is aangenomen van medebezitters van een gebrekkige opstal - in casu tevens echtelieden - tegenover elkaar. Of aan de rechtspraak betreffende shock- en affectieschade, ${ }^{27}$ de Wilnisser Dijkdoorbraak, ${ }^{28}$ enzovoort. Ik rond deze bloemlezing echter af door te refereren aan beslissingen van de Hoge Raad die niet zozeer verrassend zijn en vragen oproepen vanwege het daarin vervatte inhoudelijke oordeel, maar juist vanwege het ontbreken daarvan: de zogenoemde ' 81 RO'-beslissingen. Terwijl er de laatste jaren het nodige is gebeurd dat bijdraagt aan de kwaliteit van de cassatieadvocatuur, en enkele trouwe leveranciers van 'onzincassaties' van het tableau zijn verdwenen, doet de Hoge Raad veelvuldig zaken af met een beroep op art. 81 Wet RO. Oók zaken waarin cassatieadvocaten van naam en faam kennelijk wel heil zagen, en zelfs soms in zaken die zich naar het oordeel van de advocaat-generaal blijkbaar wel voor een inhoudelijke beoordeling leenden; zie bijvoorbeeld de zaak van verzekeraar London betreffende de eisen te stellen aan het bewijs van causaal verband in geval van whiplashachtige klachten uit februari $2015 .{ }^{29}$

\section{Kan en moet het anders, en zo ja, hoe?}

3.1. Ik heb enkele beslissingen van de Hoge Raad de revue laten passeren die, naar ik meen, illustreren dat arresten van de Hoge Raad soms meer vragen oproepen dan beantwoorden, en daarmee nieuwe rechtspraak uitlokken. Tevens zijn enkele uitspraken aan de orde gesteld die in onderlinge samenhang bezien een wat grillig resultaat opleveren of waarbij anderszins

24. Voor een uitgebreidere uiteenzetting van deze visie zij verwezen naar mijn beschouwing: Bewijs van causaal verband tussen beweerdelijk geleden beleggingsschade en schending van een informatie- of waarschuwingsplicht, in: D. Busch e.a. (red.), Aansprakelijkheid in de financiële sector (Serie Onderneming en Recht, deel 78), Deventer: Kluwer 2013, m.n. p. 129-136.

25. HR 8 februari 2013, ECLI:NL:HR:2013:BX7846.

26. HR 8 oktober 2010, ECLI:NL:HR:2010:BM6095.

27. HR 22 februari 2002, NJ 2002/240 (Kindertaxi) en HR 9 oktober 2009, NJ 2010/387 (het Vilt-arrest).

28. HR 17 december 2010, NJ 2012/155. Zie voor voorbeelden van verdere rechtspraak waartoe dit arrest blijkbaar heeft geleid en de naar aanleiding hiervan ontstane 'worsteling': JA 2014/44, ECLI:RBROT:2014:2705 en ECLI:NL:GHSHE:2014:1203. Zie wat de Hoge Raad betreft vervolgens HR 4 april 2014, ECLI:NL:HR:2014:831 (Reaal/Gemeente Deventer). Vgl. tevens HR 9 mei 2014, ECLI:NL:HR:2014:1091 (X/Gemeente Sint-Oedenrode), afgedaan op grond van art. 81 Wet RO.

29. HR 13 februari 2015, ECLI:NL:HR:2015:308 (London Verzekering/ $\mathrm{X})$. kritische kanttekeningen of althans vragen zijn te plaatsen wat betreft hun bijdrage aan de rechtseenheid of de rechtsontwikkeling. Zoals gezegd, zijn er veel meer arresten te noemen, ook op andere rechtsgebieden, die vragen oproepen. Vragen betreffende de reikwijdte van de gegeven beslissing, maar ook wat betreft de daaraan ten grondslag liggende gedachten, of zo men wil de agenda van de Hoge Raad c.q. de vraag óf er sprake is van enige agenda. ${ }^{30}$ Waarom gaat de Hoge Raad in de ene zaak heel ver in de bescherming van een gedupeerde en in een andere zaak duidelijk niet?

Voor een deel laat de door de Hoge Raad gevolgde koers zich verklaren vanuit procesrechtelijke ofwel cassatietechnische optiek. In sommige zaken kon de Hoge Raad niet veel anders dan hij heeft gedaan vanwege de inhoud van de cassatiemiddelen, die voor hem nu eenmaal leidend zijn. Ook de gebondenheid aan de feiten zoals die in lagere instantie zijn komen vast te staan, levert zekere beperkingen op en verklaart soms de uitkomst van een als verrassend ervaren arrest. Hetzelfde geldt voor de beperking van de toetsing door de Hoge Raad tot de interpretatie van het recht door de lagere rechter en de omvang en begrijpelijkheid van diens motivering. In commentaren wordt de Hoge Raad regelmatig verweten de plank misgeslagen te hebben en een 'foute uitspraak' te hebben gedaan, terwijl hetgeen de Hoge Raad volgens de criticus had moeten doen procesrechtelijk bezien in het geheel niet kon. Wat meer aandacht voor het procesrecht zou soms geen kwaad kunnen. Maar er zijn ook gevallen waarin er wel ruimte gevonden kon worden, maar de Hoge Raad deze kennelijk niet wil pakken, en zich daarom bijvoorbeeld terugtrekt achter de wal van cassatietechniek - zoals Spier het in zijn conclusie voor voormelde Whiplash-zaak verwoordt - of zich beroept op de evenmin strak getrokken grenzen van zijn rechtsvormende taak. ${ }^{31}$ Wat dit laatste betreft, is een toelichting op een dergelijke keuze, zoals bijvoorbeeld gegeven in het arrest TNT/Wijenberg, welkom en nuttig, hoewel de voorspellende waarde hiervan in het kader van toekomstige, andersoortige zaken gering is. Het blijft voor de buitenstaander spannend en moeilijk voorspelbaar waar de Hoge Raad zijn grens als rechtsvormer trekt, maar wellicht is dit voor de leden van de Hoge Raad net zo spannend en evenmin in concreto voorspelbaar.

3.2. Een ander punt is de wijze waarop de Hoge Raad opereert in zaken waarin hij invulling geeft aan open normen dan wel anderszins (wel) rechtsvormend optreedt. Zowel vanuit de rechtspraktijk als vanuit de wetenschap wordt de Hoge Raad met enige regelmaat opgeroepen zich niet te beperken tot de beslissing in de aan hem voorgelegde zaak, maar (meer) sturing te geven aan ook andere, toekomstige zaken, en met het oog hierop bijvoorbeeld concretere, duidelijkere vuistregels te formuleren en minder slagen om de arm te houden door bijvoor-

30. Voormalig president van de Hoge Raad Martens schijnt eens te hebben gezegd dat de Hoge Raad geen agenda heeft, behalve die van een grote uitgever. Zie Drion 2014.

31. Zie voor een beknopte schets van diverse opvattingen over de reikwijdte van de rechtsvormende taak van de Hoge Raad bijv. P.P.T. Bovend'Eert (m.m.v. C.A.J.M. Kortmann), Rechterlijke organisatie, rechters en rechtspraak, Deventer: Kluwer 2013, p. 279 e.v. 
beeld het hanteren van woorden als 'in beginsel', 'in het algemeen', enzovoort. ${ }^{32}$ Dit lijkt, althans op het eerste gezicht, inderdaad bij te dragen aan een betere voorspelbaarheid van de uitkomst van toekomstige zaken, maar toch heb ik hierbij mijn aarzelingen. Uitgangspunt is en dient mijns inziens te blijven de beoordeling van de voorliggende zaak ofwel de beoordeling van de ter cassatie voorliggende uitspraak (behoudens uiteraard in geval van beantwoording van prejudiciële vragen). Naar mijn mening is terughoudendheid op zijn plaats wat betreft het formuleren van algemene regels en het uitzetten van lijnen die richting moeten geven in toekomstige zaken. ${ }^{33}$ De werkelijkheid is regelmatig grilliger dan van achter de pc of vanuit de raadkamer van de Hoge Raad kan worden bedacht. Er zijn diverse voorbeelden te geven van uitspraken waarin de Hoge Raad min of meer algemene lijnen heeft uitgezet, of nieuwe wegen is ingeslagen, die in latere zaken minder gelukkig uitpakten en weer teruggedraaid, bijgesteld of afgekapt zijn. De besproken verzekeringsplicht van de werkgever is er een van. De rechtspraak betreffende de omkeringsregel is een tweede: na de veralgemening van deze regel en de zeer ruimhartige toepassing hiervan, die de kritiek opleverde dat op deze wijze het causaliteitsvereiste niet veel meer voorstelde en de vraag opriep of er sprake was van 'Amerikaanse toestanden' - aldus in 2000 het latere lid van de Hoge Raad, Coen Drion $^{34}$ - zijn de touwtjes kennelijk weer aangetrokken.

Goede voorbeelden van uitspraken waarin de Hoge Raad enerzijds richting geeft aan de lagere rechtspraak wat betreft de te varen koers in andere zaken, maar anderzijds voldoende ruimte laat voor afwijkingen als de feiten daartoe aanleiding geven, zijn wat mij betreft de zogenoemde effectenlease-arresten: De Treek/Dexia en Levob/Bolle. ${ }^{35}$ In aansluiting op het verzoek in deze proefprocessen een oordeel te geven op een zo hoog mogelijk abstractieniveau, dat richting zou kunnen geven in de vele andere effectenleasezaken, formuleert de Hoge Raad bepaalde uitgangspunten wat betreft het causaal verband. De Hoge Raad geeft hierbij uitdrukkelijk aan dat in individuele zaken niet in onbeperkte mate kan worden geabstraheerd van de omstandigheden van het geval. Hoewel ook deze uitspraken vragen oproepen, met name wat betreft de reikwijdte in geval van andersoortige normschendingen, heeft de Hoge Raad in voormelde effectenleasezaken naar mijn mening een goede balans weten te vinden tussen enerzijds richting geven en anderzijds het uitgangspunt dat geschillen in

32. Hierover bijv. T. Hartlief, Gezichtspunten, vingerwijzingen en vuistregels. Kan dat anders?, NTBR 2011, p. 25-28.

33. Vgl. (daarentegen?) de president van de Hoge Raad in: N. Huls, Bruggen bouwen. Interview met de nieuwe president van de Hoge Raad, Maarten Feteris, NJB 2015, p. 489-490. Feteris geeft aan wel te houden van (duidelijkheid en) brede arresten 'waar veel mensen wat aan hebben'. Tegen dat laatste ben ik overigens ook geenszins. Vgl. in dit verband tevens (o.a.) G. de Groot, Motiveren van rechterlijke uitspraken: een evenwichtsoefening, in: G.J.M. Corstens e.a. (red.), 175 jaar Hoge Raad der Nederlanden, Den Haag: Boom Juridische uitgevers 2014, p. 113-178.

34. NJB 2000, p. 1958

35. Respectievelijk HR 5 juni 2009, NJ 2012/182 en HR 5 juni 2009, NJ 2012/183 m.nt. J.B.M. Vranken onder NJ 2012/184. Vgl. ook HR 27 november 2009, ECLI:NL:HR:2009:BH2162, JOR 2010/43 m.nt. K. Frielink (World Online). principe op basis van de feiten van het onderhavige geval dienen te worden beslecht. ${ }^{36}$

3.3. Een punt waarop naar mijn mening nog wel winst valt te boeken, is de formulering van uitspraken. Uitspraken behoeven niet in 'jip-en-janneketaal' te worden geschreven. Hoewel de uitspraak gericht is tot partijen, is het recht regelmatig te ingewikkeld om een daarop gebaseerde beslissing, althans op het niveau van de Hoge Raad, in voor partijen daadwerkelijk begrijpelijke bewoordingen op papier te zetten. Het is wat mij betreft de taak van de advocaat de uitspraak zo nodig op een voor zijn cliënt begrijpelijke wijze nader aan deze uit te leggen; rechtsbijstand is verplicht en verplicht (noblesse oblige), niet alleen tot een vertaalslag van het verhaal van de cliënt naar een deugdelijk betoog in rechte, maar zo nodig ook tot een nadere toelichting van de gang van zaken in rechte en de uitkomst daarvan tegenover de cliënt. Het komt echter regelmatig voor dat de formulering van arresten niet alleen tot misverstand of althans tot vragen bij partijen leidt, maar ook bij juristen. Wederom een enkel voorbeeld.

Allereerst nogmaals de door sommigen vermaledijde omkeringsregel, waarvan Vranken eens heeft gezegd dat er hectoliters drukinkt nodig zouden zijn om de betekenis en de reikwijdte hiervan in al zijn aspecten en technische details te bepalen. ${ }^{37}$ Nadat is gebleken dat zijn rechtspraak vragen en bovenal kritiek oproept, beoogt de Hoge Raad in de zogenoemde novemberarresten uit 2002 kennelijk duidelijkheid te verstrekken. ${ }^{38}$ In deze arresten wordt de omkeringsregel, zoals deze voordien is aangenomen, door de Hoge Raad toegelicht en uitgewerkt, aldus zijn eigen woorden. In feite worden echter de touwtjes aangehaald en worden de voorwaarden voor toepassing van de omkeringsregel aangescherpt, zo valt uit de uitspraak alsook uit de daarop volgende rechtspraak af te leiden. Maar zeg dit dan met zoveel woorden. Dan zouden wellicht veel van de hectoliters inkt waarover Vranken sprak, bespaard kunnen zijn.

Een ander, en wat mij betreft ultiem voorbeeld van een uitspraak die tot minder verwarring had geleid als de Hoge Raad het beestje bij z'n naam had genoemd en duidelijk(er) had gezegd wat hij bedoelde, is het arrest Nefalit/Karamus uit maart 2006. ${ }^{39}$ Ter herinnering: het ging hier om de aansprakelijkheid van werkgever Nefalit jegens oud-werknemer Karamus voor de schade die deze ondervond vanwege zijn longkanker. Karamus stelt dat deze longkanker was te wijten aan de blootstelling aan asbest in het kader van zijn werkzaamheden voor Nefalit. Nefalit betwist dit en stelt dat deze schade wellicht aan andere oorzaken is te wijten, waaronder in het bij-

36. Iets anders is dat feitenrechters regelmatig (b)lijken te volstaan met het overnemen van de door de Hoge Raad geformuleerde 'regels' en weinig of geen ruimte (b)lijken te bieden voor afwijking op basis van de feiten en omstandigheden van het desbetreffende geval c.q. bewijslevering ter zake.

37. Noot onder het arrest Oude Monnink Motors, HR 19 januari 2001, NJ $2001 / 525$.

38. HR 29 november 2002, NJ 2004/304 (TFS c.s./Nederlandse Spoorwegen c.s.) en HR 29 november 2002, NJ 2004/305 m.nt. DA (Kastelijn/ Gemeente Achtkarspelen).

39. HR 31 maart 2006, NJ 2011/250 m.nt. T.F.E. Tjong Tjin Tai. 
zonder de omstandigheid dat Karamus heeft gerookt. Het was niet mogelijk om met een voldoende mate van zekerheid vast te stellen wat de daadwerkelijke oorzaak van de longkanker van Karamus was. De Hoge Raad oordeelt dat de rechter in een dergelijk geval 'de werkgever tot vergoeding van de gehele schade mag veroordelen, met vermindering van de vergoedingsplicht van de werkgever in evenredigheid met de, op een gemotiveerde schatting berustende, mate waarin de aan de werknemer toe te rekenen omstandigheden tot diens schade hebben bijgedragen'. In het algemeen wordt in deze beslissing de aanvaarding van een zogenoemde proportionele aansprakelijkheid gezien, ofwel een aansprakelijkheid naar rato van veroorzakingswaarschijnlijkheid. Op de door de griffier van de Hoge Raad verzorgde samenvatting op internet wordt deze uitspraak eveneens aangekondigd als een aanvaarding van het in de literatuur verdedigde leerstuk van de proportionele aansprakelijkheid. ${ }^{40}$ Anders Jeroen Kortmann. ${ }^{41}$ Hij stelt dat uit het arrest Nefalit/Karamus niet mag worden afgeleid dat de Hoge Raad een proportionele aansprakelijkheid, in de zin dus van een aansprakelijkheid naar rato van veroorzakingswaarschijnlijkheid, heeft aanvaard, maar er (slechts) sprake is van een 100-procentaansprakelijkheid van werkgever Nefalit minus het percentage eigen schuld van werknemer Karamus. ${ }^{42}$ Kortmann is in zijn redenering gevolgd door Hartkamp en Sieburgh. ${ }^{43}$ In het arrest Fortis/Bourgonje van december $2010^{44}$ omzeilde de Hoge Raad deze kwestie door te spreken van 'de rechtsregel van het arrest Nefalit/Karamus' dan wel het hanteren van een vergelijkbare aanduiding, in plaats van de term proportionele aansprakelijkheid te hanteren en/of aan te geven wat voor soort aansprakelijkheid in het arrest Nefalit/ Karamus nu eigenlijk was bedoeld. Eerst in de arresten Nationale Nederlanden/zoon en moeder ${ }^{45}$ en Deloitte Belastingadviseurs/H en $\mathrm{H} \& \mathrm{H}$ Beheer ${ }^{46}$ uit december 2012 makt de Hoge Raad expliciet duidelijk dat hij in het arrest Nefalit/ Karamus de rechtsregel van de proportionele aansprakelijkheid heeft aanvaard en dat dit betekent een aansprakelijkheid in evenredigheid met de in een percentage uitgedrukte kans dat de schade door de normschending van de desbetreffende partij is veroorzaakt. Waarom dit niet gelijk gezegd, of althans in de geboden herkansing in 2010 in het arrest Fortis/Bour-

40. Zie <http://rechtennieuws.nl/7470/uitspraken-aansprakelijkheid-voor-de -gevolgen-van-asbest.html>.

41. J. Kortmann, Karamus/Nefalit: proportionele aansprakelijkheid?, NJB 2006, p. 1404-1412.

42. In het arrest Nefalit/Karamus maakte dit overigens niet uit, maar een en ander zou wel verschil maken indien er sprake zou zijn van meerdere werkgevers, waarbij een werknemer aan asbest zou zijn blootgesteld. Dan maakt het immers verschil of iedere werkgever, die er niet in slaagt aan zijn zorgplicht te hebben voldaan, aansprakelijk is voor 100 procent van de schade minus het aan de werknemer toe te rekenen aandeel, dan wel iedere werkgever aansprakelijk is naar rato van de kans dat de omstandigheden waaronder de werknemer bij hem heeft gewerkt de oorzaak van diens letsel zijn.

43. Asser/Hartkamp \& Sieburgh 6-II 2013/81a.

44. HR 24 december 2010, NJ 2011/251 m.nt. T.F.E. Tjong Tjin Tai.

45. HR 14 december 2012, NJ 2013/236 m.nt. S.D. Lindenbergh onder NJ $2013 / 237$.

46. HR 21 december 2012, NJ 2013/237 m.nt. S.D. Lindenbergh. gonje, toen het debat over de interpretatie van zijn uitspraak de Hoge Raad ongetwijfeld bekend was?

3.4. Min of meer in het verlengde van het vorige punt ligt het zogenoemde 'omgaan' van de Hoge Raad. Soms is kenbaar dat dit eraan zit te komen, soms niet. Dat is op zichzelf wat mij betreft niet bezwaarlijk: het belang van voorspelbare rechtspraak gaat niet zo ver dat het in de weg staat aan het inslaan van een andere koers wanneer daarvoor gelet op de maatschappelijke ontwikkelingen, gewijzigde inzichten of anderszins goede argumenten bestaan. Echter, ook op dit punt wordt er vanuit de rechtspraktijk en de wetenschap regelmatig het nodige 'gespeculeerd', ook op hoog niveau. ${ }^{47}$ Is er sprake van een koerswijziging? Is de Hoge Raad om? Het betrachten van enige openheid en het verstrekken van achtergrondinformatie over de werkwijze van de Hoge Raad, die helpt bij het lezen en interpreteren van diens arresten, zoals recent is geschied door Drion, ${ }^{48}$ zijn in dit verband behulpzaam. Het verdient niettemin hiernaast aanbeveling dat de Hoge Raad, als hij omgaat en terugkomt op een eerdere beslissing, dit expliciet aangeeft, zoals (bijvoorbeeld) geschied in HR 27 maart 2015, ${ }^{49}$ betreffende de mogelijkheid tot het verkrijgen van een verklaring voor recht. ${ }^{50}$ De Hoge Raad overweegt hierin expliciet dat, voor zover in zijn arrest uit 1951 anders is geoordeeld, hij daarvan terugkomt. Dat is klare wijn!

3.5. Dan het geschetste grillige beeld dat op sommige terreinen, waaronder in het bijzonder het aansprakelijkheidsrecht, is ontstaan en een gevolg is van de rechtspraak van de Hoge Raad. Ik memoreer de uiteenlopende positie van werknemers met letselschade, maar ook de positie van letselschadeslachtoffers ten opzichte van gedupeerde beleggers. Ik realiseer mij dat een en ander te maken heeft met de omstandigheid dat de Hoge Raad het recht vormt op basis van de min of meer toevallige aanvoer van zaken waarin zijn oordeel wordt gevraagd en hij daardoor stukje bij beetje inkleuring geeft aan het recht. Toch kan het wellicht geen kwaad eens naar het totaalplaatje te kijken en hiermee, binnen de grenzen van het mogelijke, rekening te houden bij de beoordeling van individuele zaken ofwel bij de toetsing van uitspraken van lagere rechters in individuele zaken. Dit geldt in het bijzonder voor rechtsgebieden zoals het aansprakelijkheidsrecht, waarop rechtsvorming door de Hoge Raad een zwaar stempel drukt.

3.6. Tot slot de eerder aangehaalde praktijk rond het gebruik van art. 81 Wet RO. Ik onderschrijf zonder meer de gedachte dat de Hoge Raad zijn menskracht dient te kunnen aanwenden ten behoeve van zaken die er vanuit zijn taakstelling bezien daadwerkelijk toe doen en waarin dus kwesties betreffende de rechtseenheid dan wel de rechtsvorming aan de orde

47. Zie bijv. J. Spier, Een nieuw tijdperk?, AV\&S 2014, afl. 2, p. 33-38.

48. Zie Drion 2014, alsook 'Soms is de Hoge Raad tot op het bot verdeeld', interview, Mr. 2015, p. 18-23.

49. HR 27 maart 2015, ECLI:NL:HR:2015:760 (AIG Europe Limited/M).

50. Vgl. (in kritische zin) wat betreft het 'verkapte' omgaan door de Hoge Raad ook Wibier 2015, p. 56 en F.M.J. Verstijlen, Hoe om te gaan met 'omgaan'?, TvI 2015/27. 
zijn. De maatregelen die de afgelopen jaren zijn genomen om dit zo veel als mogelijk te bewerkstelligen, juich ik zeer toe. Echter: ik kan mij niet aan de indruk onttrekken dat het afdoen van zaken op grond van art. $81 \mathrm{Wet} \mathrm{RO}$ wat is doorgeslagen. De hieruit voortvloeiende onvoorspelbaarheid is bij een goede cassatieadvocatuur naar ik meen niet te rechtvaardigen. En van onvoorspelbaarheid is alleen sprake bij een goede cassatieadvocatuur/cassatieadvocaat. Immers: in geval van een slechte cassatieadvocaat die bot vangt, is van onvoorspelbaarheid geen sprake.

Tot zover mijn bijdrage aan het debat over cassatie en de taak van de cassatierechter. 